\title{
Fernando de Castro: Cajal's man on the the peripheral nervous system
}

\author{
Francisco Ros-Bernal ${ }^{1}$, Fernando de Castro ${ }^{2^{*}}$ \\ ${ }^{1}$ Grupo de Neurotecnología, UP Medicina, Universitat Jaume I, Castellón de la Plana, \\ Spain \\ ${ }^{2}$ Grupo de Neurobiología del Desarrollo-GNDe, Instituto Cajal-CSIC, Madrid, Spain.
}

*Corresponding Author: Fernando de Castro. Grupo de Neurobiología del DesarrolloGNDe, Instituto Cajal-CSIC, Madrid, Spain. Correspondence and requests for materials should be addressed to F.dC. (email: fdecastro@cajal.csic.es)

Running title: Peripheral nervous system and artery chemoreceptors

All grant information in the following format: Grant sponsor(s): Spanish Ministry of Science (former Ministry of Economy, Industry, and Competitiveness); Fundación Inocente Inocente (Spain); Grant number(s): SAF2016-77575-R, RD16/0015/0019. 


\section{Introduction}

With the international recognition of Santiago Ramón y Cajal for his extraordinary scientific performance (International Moscow Prize, 1900) the Spanish government allocated budget to build a fully-equipped laboratory in Madrid to continue with the studies on the fine structure of the nervous system and to contract collaborators to help the maestro in his feat (Ramón y Cajal, 1923; Andrés-Barquin 2002; de Castro, In Press). The first one to arrive was Francisco Tello but fast there were a plethora of young enthusiastic collaborators dreaming to be neurohistologists, neurologists or what we currently know as neuroscientists: Nicolás Achúcarro, Gonzalo R. Lafora, Pío del Río-Hortega, and the youngsters Fernando de Castro and Rafael Lorente de Nó, to circumscribe these names to the main characters in what we know under the collective name of Spanish Neurological School or, in colloquial terms, Cajal School or the School of Madrid (de Carlos and Pedraza 2014; de Castro, In Press).

However, the international recognition (Moscow Prize -1900-, Helmholtz Medal -1905-, Nobel Prize in Physiology or Medicine -1906-) does not granted Cajal with the universal acceptance of his theories about the organization of the brain. The reticularists claimed for the syncytial connectivity between the different neural structures, as was the case for Camillo Golgi (who shared with Cajal the Nobel Prize in 1906), and as the uncontested paladin of "the neuron theory", Santiago Ramón y Cajal remained active in this neuronist-vs-reticularists war for the rest of his life (Ramon y Cajal 1933; de Castro, 1981; de Castro, In Press). The spirit of school was one of the main characteristics of the Spanish Neurological School, and in this scenario, all its members were implicated in this capital scientific controversy, extending it to every terrain of work. This is where Fernando de Castro (Madrid, 1896 - Madrid, 1967; Fig. 
1A; Fig. 2D) played a principal role: he extended the scientific fight to the Peripheral Nervous System, where Cajal has put relatively small attention to that date. After a brief biographic note about de Castro, we will review here his performance in the study of the structure of the peripheral ganglia (sensitive, sympathetic, parasympathetic) and the innervation of the carotid region (baroreceptors and de Castro's most known discovery: the chemoreceptors within the carotid body).

\section{A brief biography of early Fernando de Castro}

Fernando de Castro was born in Madrid (February $\left.25^{\text {th }}, 1896\right)$, the capital city of Spain, just two years before the loss of the last pieces of its vast colonial empire (Cuba, Puerto Rico and the Philippine Islands), what dumped the country in a dramatic crisis of identity. Young de Castro studied Medicine in the Medical School of Madrid (Universidad Central) and attracted as many by the charismatic figure of Santiago Ramón y Cajal, his teacher of Histology and Pathology. His first assay to join Cajal's lab was unfruitful, but he could join the branch leaded by Nicolás Achúcarro, focused in the pathology of the nervous system. There, young de Castro brilliantly learnt histological technique and studied the Golgi apparatus in the gustative buttons and, in agreement with the main research line of Achúcarro, the gliogenesis and glioarchitecture of nerve tissue, that de Castro studied in the olfactory bulb (de Castro 1916a; de Castro, 1916b; de Castro, 1920a; de Castro, 1920b; de Castro, 1920c). He particularly appreciated these neuroglia-focused studies (Gómez-Santos 1968; de Castro 2009a).

Unfortunately, Achúcarro became seriously ill and prematurely died on April $23^{\text {rd }}, 1918$, at the age of 37 years (de Castro 1981; Tremblay et al. 2015). Santiago 
Ramón y Cajal lost one of his most promising collaborators but previously informed about the progress by young de Castro on histological technique, claimed this to join the Laboratorio de Investigaciones Biológicas, directly under Cajal's direction (de Castro, 1981; Gómez Santos, 2009; Fig. 1A). Fernando de Castro worked with the Maestro until the death of the latter in 1934: indeed, Tello and de Castro were the only disciples present when Santiago Ramón y Cajal died, and de Castro did the past therapeutic effort trying to keep Don Santiago alive (de Castro, In Press). Cajal entrusted de Castro to teach and supervise the formation in neurohistology of all the scientists visiting the Laboratorio from 1924 to 1932: this gives the perspective of the high degree of technical formation reached by Fernando de Castro, as well as the professional appreciation that Cajal granted him. He supervised scientists as Howard W. Florey (Nobel Prize in Physiology or Medicine awardee in 1945), Deszo Miskolzi (founder of Hungarian Neuroscience and translator of Cajal into German), or Clemente Estable (founder of Neuroscience in Uruguay). To ice on the cake, Cajal entrusted de Castro to compile the protocols of neurohistological techniques used and developed under the shadow of the Maestro for decades to publish them in maybe the first ever textbook purely dedicated to Neurohistological procedures (Ramón y Cajal and de Castro 1933 -recently translated into English by first time: Merchán et al. 2016-).

\section{De Castro unravels the organization of sensitive ganglia}

Historically, many histologists had tried to resolve the functional and morphological details of the peripheral nervous system, but studies remained technically and logistically very challenging. After 1885, W. H. Gaskell and J.N. Langley significantly progressed in the knowledge of the organization of the vegetative system, introducing 
the "autonomic nervous system" to denominate it as well as discovered that each structure was supplied by two sets that they presumed of antagonist sympathetic with a catabolic function- and parasympathetic fibers -mainly anabolic- (Langley, 1903; Marani \& Lakke 2012). The debate between supporters of "neuronism" and "reticularism" was even bitter in this particular field: an example of this fierce but cooperative dispute was the origin of the interstitial Cajal cells in the gut, fibroblastic according to reticularist hypothesis against the neuronism movement led by Cajal who proposed their neural origin. The study of sensory ganglia derived into important debates on the intraganglionic axon collaterals and the nature of the "atypical", tangled or with ball-shaped processes cells" observed. The scientific community was struggling about the nature of these atypical forms, were these cells observed in the sensory ganglia the consequence of pathological processes affecting ganglia or can they be observed in normal conditions. On this scientific framework, it was crucial for Cajal's decision: he entrusted his young pupil Fernando de Castro to work on the microscopic structure of the sensory ganglia, which was the basis of his Ph.D. thesis, defended in 1922 (Fig. 1B) in a work that received the Rodríguez Abaytúa Prize from the Royal National Spanish Academy of Medicine that year (de Castro 1981).

The commission received from Cajal, induced de Castro to accumulate histological material (somatic and sensory plexiform ganglia) from autopsies for his study: he collected "normal" tissue from fetal to young adults who died under accidental circumstances and "pathological cases" from several infectious diseases, cancer, alcoholism... (Fig. 1C-D). Applying the silver methods of his mentors, Cajal and Achúcarro, de Castro corroborated that monopolar neurons were the most abundant cell type in the normal sensory ganglia, improving what Cajal and Marinesco had 
suggested years before, as well as evidenced that in prenatal pathological condition this type of cell was even more abundant, confirming Cajal's observations that most of these cells arise within a single ganglion in cervical and lumbar ganglia (de Castro 1922). Paradoxically, although Giuseppe Levi and Tullio Terni had previously detailed a correlation between the size of the ganglionic neurons and the volume of peripheral tissue innervated by its axon (Terni 1914), de Castro just described this observation relieving it of any theoretical interpretation, may be induced by the fact that these observations had been made in reptiles: since the work of Dale Purves in the sympathetic system, we know that the relationship between the size of the target tissue correlates with the size of the neurons (Purves \& Lichtman, 1985; de Castro et al., 1997). Several observations by de Castro confirmed prior descriptions (ex.: the presence of bipolar cells in normal ganglia) but other discarded previous findings such as those neurons with intraganglionic branches (those that the Russian histologist Alexander Dogiel have classified as type VIII) were exclusive from pathological circumstances (Dogiel 1908; de Castro 1922). Fernando de Castro suggested that Dogiel's types V, VI, and VII should be identified as variations of the same fenestrated cell typology (Dogiel 1908; de Castro 1922). Regarding the controversy between Cajal and Dogiel about the origin of satellite cells in somatic sensory ganglia, using elegant histological techniques, de Castro evidenced their ectodermal nature and their function as "neuro-neuroglial symbiosis" (de Castro 1922). All these conclusions were abidingly appropriated and universally accepted, and included in the chapter requested by the neurosurgeon and neuropathologist Wilder $\mathrm{S}$. Penfield for his acclaimed treaty on the Nervous System published one decade after (de Castro $1932 a)$. 
De Castro also targeted novel discussions such as neuronal regeneration by virtue of his findings in ganglia of pathological samples (de Castro 1922): against the trophic hypothesis postulated by Cajal and others, he was more inclined to wonder if the ball-ended processes arising from ganglia after nerve transection had a neuronal restorative role. Beyond a mere de Castro's speculation this was founded in previous in vitro regenerative studies (Marinesco and Minea 1912; Marinesco and Minea 1914). De Castro's interest in nerve regeneration went beyond as during the decade of 1930 he undertook complex experiments including re-innervation and crossed anastomosis between autonomic motor fibers and sensory ganglia to demonstrate the nature of the chemoreceptors in the carotid body (see below in this article; summarized in: de Castro 2009a; de Castro 2009b). This performance in the sensitive ganglia yielded significant scientific revenues to Fernando de Castro, not only because he obtained the highest qualification in his Ph.D. thesis but because it generated an outstanding must: the definitive intellectual and technical recognition by the Maestro, Santiago Ramón y Cajal.

\section{De Castro conquests the vegetative ganglia ${ }^{1}$}

Spurred by both the success of his contributions on human somatic sensory ganglia, and the lack of studies with neurofibrillary methods at that time, Fernando de Castro decided to address the histological characterization of autonomic ganglia. The results of his labor during 25 years of scientific contributions focused in the intercellular connections in the sympathetic ganglia (de Castro 1923a; de Castro 1923b; de Castro, 1933; de Castro, 1951a; Fig. 1C-D). As previously Ehrlich had detailed in the frog

\footnotetext{
${ }^{1}$ For brevity of the present work, many details on the work of Fernando de Castro in the peripheral ganglia summarized before (de Castro, 2016) have not been included now.
} 
(Ehrlich 1888), Fernando de Castro described that the preganglionic connections wrap in spirals onto ganglionic cells to form the pericellular nests also in mammals (de Castro 1923a; de Castro 1923b; de Castro 1932b). He also confirmed that these pericellular nests were receptive sites for specific synaptic contacts from preganglionic fibers (de Castro 1923b; Fig. 1D). Subsequent studies demonstrated that these particular structures, forming what they called the "receptive plaques", were the most frequent form of intercellular connection in the sympathetic ganglia. A decade had to elapse before synapses were proposed to be present at the terminal boutons of the preganglionic fibers (de Castro 1930; Kolossow \& Sabussow 1932; Lawrentjew 1934).

De Castro elegantly described that in each ganglion cells of three types (big, medium and small size neurons) were weaving neurites together, following an apparent arbitrary distribution (de Castro 1932b; de Castro 1937; de Castro 1950). This description gave morphological substrate to previous electrophysiological recordings indicating that each type of preganglionic fiber formed synapsis with one exclusive type of ganglionic cell (Billingsley and Ranson 1918; de Castro 1923a; de Castro 1932a; de Castro 1932b; de Castro 1937; de Castro 1950). It was in this moment when anatomy and histology catch up physiology in the PNS, after the pioneer studies of Henry Dale and Otto Loewi demonstrating the chemical neurotransmission and the first neurotransmitters (Dale, 1914; Loewi, 1921; Dale, 1935). As stated before, Fernando de Castro observed that axons of neurons in the myenteric ganglia, like Dogiel's Type II cells, project either to other neurons within the same ganglia or in other neighbor ganglia, but never end in the enteric mucosa. De Castro dedicate several times to elucidate the nature of intraganglionic synapses (Fig. 1D), he was able to demonstrate that the number of intraganglionic synapses is significantly larger than 
that of terminal boutons (Fig. 1E-F; de Castro and Herreros 1945). Paradoxically it wasn't until the XXI ${ }^{\text {st }}$ century when de Castro's description of "the synaptic boutons close to astrocytes" become meaningful in the term "tripartite synapses" (Araque et al. 1999; Perea et al. 2009). Fernando de Castro's perception of the anatomy and physiology of the PNS has come down to us today. In this respect, he defined a glial veil around ganglionic neuronal components that forms a sort of "neuronal atmosphere" which protects axons once they lose their myelin sheaths (de Castro 1937; de Castro \& Herreros 1945): he even hypothesized that expansions emerging of Schwann cells constituted the intermediate portions of synapses, an obvious error since our current perspective that was participated by the great Río-Hortega, too (de Castro 1942; del Río-Hortega and Prado 1942). Most parts of de Castro's scientific articles were dedicated to the elegant and structured analysis of the cytoarchitecture of sympathetic and parasympathetic autonomic motor ganglia, with a special emphasis in the synapses network, not only in humans but also in other primates and several large mammals (de Castro 1930). This interest in synapses exemplifies the remaining career of de Castro as a researcher.

\section{How Fernando de Castro demonstrated the existence of arterial chemoreceptors ${ }^{2}$}

In the mid-1920s, Heinrich Ewald Hëring published the results of numerous experiments in which the electrical stimulation of the carotid sinus and of its nerve which he called "sinus nerve"- induced a similar effect to its mechanical pressure, and

\footnotetext{
${ }^{2}$ As well as above and in the interest of the concreteness of our current work, readers interested in a detailed revision about the state-of-the-art regarding the nature and function of the carotid region, as well as a detailed depiction of de Castro's peripeteia in this particular field, can consult specific revisions in the field (de Castro, 2009a; de Castro, 2009b).
} 
the elevation of pressure inside the carotid sinus generated a blood pressure-lowering effect, what he defined as the "sinus reflex" (Fig. 2A-C; Hëring 1923; Hëring 1924). Not far from Hering's lab, coetaneous Belgian physiopharmacologists led by Heymans father (Jean-François) and son (Corneille) wrote that "main regulation of respiration depends on the cardio-aortic region, and it is conditioned by the pressure and composition of circulating blood" (Heymans \& Heymans 1927).

But the Spanish Neurological School was neither uncaring nor indifferent to the study of the innervation of the carotid-aortic region and its function. As by the middle of the 1920s, the detailed anatomical organization of the innervation of the carotid region (including the carotid body $-\mathrm{CB}-$ ) remained a mystery, Fernando de Castro decided to approach the study of the aorto-carotid region from a different angle: he studied the nature and origin of the nerve fibers innervating this region, the way the nerve fibers end on the cells and the cellular phenotype (Fig. 2D). De Castro achieved a crucial step forward when he fixed entire heads of experimental animals adding nitric acid to traditional fixatives, which allowed him to use the famous Cajal's reduced silver impregnation method in well preserved nervous structures within their skeletal protections (de Castro 1925). Moreover, this technique was particularly ideal for studying peripheral nerve structures such as the glomus caroticum or $\mathrm{CB}$, because this procedure reduces the staining of connective tissue (Fig. 2E; de Castro 1926).

Although during his first approach Fernando de Castro used several different animal species (both adults and embryos, from small rodents to humans), to study the innervation of the $\mathrm{CB}$ and the carotid region, in general, he focused in cat and dog histological preparations where either the cervical sympathetic chain and/or the glossopharyngeal had been resected. There he then described the presence of a 
periglandular plexus constituted by an evident $C B$ surrounded by nerves, plexus that is not as conspicuous in rodents or humans, for example. Independently of its morphology, the fibers surrounding the CB showed three origins: i) the most significant parts were unmyelinated fibers originating in the sympathetic superior cervical ganglion; ii) the second group in importance was constituted by middle-sized myelinated fibers coming from the intercarotid branch of the glossopharyngeal nerve (IX-c nerve) and suggested the name "nerve intercarotidum", instead of Hering's "sinus nerve" (not in vain, this nerve would contain not only sensory fibers innervating the carotid sinus region but also sensory fibers innervating intraglomerular vessels and the $\mathrm{CB}$ itself); iii) finally, the smallest cluster was represented by fibers escaping from the pharyngeal branch of the vagus nerve (X-c nerve) (de Castro 1926).

Based on his histological observations, Fernando de Castro proposed that the CB was not a paraganglion but a chemoreceptor since he observed one caudal pole next to blood vessels ("pôle sanguine") and the opposite close to nerve endings ("pôle nerveux"). Further, he demonstrated that the fibers of the intercarotid branch of the IX-c nerve ran into the $C B$ most commonly at this cephalic pole constituting the interstitial plexus. Most of these myelinated fibers lose their myelin when dividing into the CB. Encircling every cluster of parenchymatous cells, de Castro identified the periglomelular plexus, constituted by groups of fibers from the interstitial plexus. From this periglomerular plexus ran unmyelinated fibers associated with capillaries to form the intraglomerular plexus, evident and complex in most mammalian species but even more in the human CB (de Castro 1926).

Although de Castro's study profusely described the anatomy of the CB, there were no clues about its functional significance. De Castro had demonstrated that the 
$\mathrm{CB}$ was not a vital but not a rudimentary organ: its complex and profuse innervation and vascularization supported the notion of a crucial role in the regularization of arterial blood pressure. With particular emphasis in his publication dated in 1928 and intermittently in successive papers until the end of his scientific career, Fernando de Castro continued his detailed study to elucidate the answer to these questions (de Castro, 1928; de Castro, 1940; de Castro, 1944; de Castro, 1951b; de Castro, 1962; de Castro \& Rubio, 1968).

\section{Fernando de Castro sought out the physiological implications of the Carotid Body}

At the time de Castro published his original paper in 1926, there was a great controversy about Hëring's reflex. While Hëring theorized that the carotid sinus induced it, Drünner postulated that the real inductor of Hering's reflex was the CB (Drüner, 1925; Hëring, 1924). Conscious of this controversy, Fernando de Castro, always sensitive to adequate the histological technique to the problem raised, used Ërlich-Dogiel methylene blue reaction and Bielschowsky's silver method (modified by Boecke $^{3}$ ) to observe Cajal stained tissue from various species including humans. De Castro pursued two objectives: i) to confirm the presence and detail the innervation of the carotid sinus; (ii) to study the innervation and characterize the receptors of the $\mathrm{CB}$ (de Castro, 1926; in a historic perspective, please read: Gallego, 1981; de Castro, 2009b). He also described that the carotid sinus was present in all the studied species (rodents, cows, monkeys, and humans) irrespective of age, consistent with Hëring's previous study (Hering 1927). As an exception to this common finding, he noticed that

\footnotetext{
${ }^{3}$ In 1924, Fernando de Castro worked for a brief postdoctoral stage in the laboratory of Jan Boecke, at Utrecht (The Netherlands). At that time, Boecke was still a conspicous reticularist (Gómez Santos, 2009; de Castro, 2016).
} 
the $C B$ of the human fetus was not a macroscopically evident structure. This observation corrected the hypothesis generally accepted by the international scientific community at that time about the nature of the carotid sinus as a pathological malformation or anecdotal elongation of the carotid bifurcation (de Castro 1928; de Castro, 2009b). Also in this original paper, de Castro detailed the sensory innervation of the carotid region, where fibers concentrate immediately preceding the thinnest part of the internal carotid artery, close to its origin (Fig. 2E; de Castro 1928). De Castro evidenced the same distribution at the carotid artery in all the animal species studied, which reflects the robustness of his ascertainment.

After Fernando de Castro had defined the fibers distribution, he characterized the two different types of sensory receptors: either "disperse" or "circumscribed". He showed that nude terminal ramifications of the fibers crossed even the deepest part of the adventitial layer of the artery. These nude terminals would enable to detect the volumetric changes due to fluctuations in the volume of the vessel. However, de Castro failed to detect the elastic fibers with the silver method, preventing him from studying the close relation between the elastic fibers and the baroreceptors in the kinetics of vasodilation (de Castro, 2009b).

Finally, to shed light on the controversy about the nature of carotid sinus innervation, Fernando de Castro either ablated the sympathetic ganglia of the cervical chain or sectioned the glossopharyngeal, vagus or spinal nerve proximal to their respective sensory ganglia. No sign of degeneration in the terminals innervating the carotid sinus was found in any case, which led him to conclude that the fibers that innervate the carotid sinus must be sensory (de Castro 1928). The results extracted from Fernando de Castro experiments (de Castro 1926; de Castro 1928) combined with 
the physiological studies of Heinrich Hëring (Hëring 1927) validated the morphological basis of the "sinus reflex", and ruled out the hypothesis proposed by Drüner.

Once we have construed de Castro's role as decisive in this controversy, let us describe how he targeted the description of the $\mathrm{CB}$ and the chemoreceptors (Fig. 2E). In light of the outcome of the ablation experiments described above, he reconsidered the generally accepted glandular nature of the CB. The ablation of the sympathetic ganglia of the cervical chain induced a general degeneration, but a few sympathetic fibers originated from the sympathetic neurons of the microganglia presented within the CB itself (de Castro 1926). On the contrary, when Fernando de Castro sectioned the glossopharyngeal nerve, he almost devastated the fibers forming the nervous plexus in the $C B$ and the terminals connecting with glomic cells. From these previous results, de Castro concluded that the CB didn't meet the criteria to be considered a paraganglion (de Castro 1928).

De Castro was especially perturbed because he had been unable to find a function for the $\mathrm{CB}$. The idea that the $\mathrm{CB}$ could regulate the arterial pressure regularly crossed his mind. Contrary to what he expected, the destruction of the terminals that innervate the carotid sinus and the subsequent electrical stimulation of the distal segment of the intercarotid nerve (preserved in the case of the cat due to its emergence before the point where the IX-c nerve was sectioned ) did not provoke any relevant vasoconstriction of the artery: de Castro's experiments contradicted the possibility that the CB regulated arterial pressure, as it was suggested by Drüner and Jacovici (Drüner 1925; Jacobovici et al. 1928). In the second series of experiments in cats and dogs, Fernando de Castro sectioned the glossopharyngeal (IX-c nerve) and vagus (X-C nerve) and scrutinized its effects on the CB: paradoxically, he found a 
massive degeneration of the fibers (de Castro 1928). He deduced that sensory neurons from the nuclei of glossopharyngeal and vagus nerves innervated the CB. Based on the different sensory nature of this innervation to that which determines arterial pressure through Hering's "sinusreflex" (Fig. 2A-C), Fernando de Castro postulated that these nerve receptors within the $C B$ would detect changes in the chemical composition of the blood: while blood pressure demands a more imperative control by baroreceptors in the carotid sinus, the qualitative changes in the composition of the blood should be detected by the chemoreceptors of the CB (de Castro 1928). Other findings also supported this: as the baroreceptor terminals were not in direct contact with the circulating blood, they would hardly detect the changes in its composition. Rather, de Castro proposed that the glomic epithelial cells should carry through this task via a bulging "active protoplasmic process" and then this information would be centripetally conducted to the nerve terminals.

Nevertheless the direct physiological demonstration of the chemoreceptive function of the $C B$ was due to Corneille Heymans (Fig. 2G-H), although in the reorientation of his work in Ghent towards the CB was incontrovertibly influenced by the anatomical descriptions of Fernando de Castro (Gallego, 1981; de Castro, 2009b). The alembicated way followed by de Castro to try to demonstrate this, as well as the social and political situation that involved Spain since 1931 (regime's change to the Second Republic, political instability including assays of coupes d'état and revolutions, the dead of Cajal -1934- and, finally, the disastrous burst of the Spanish Civil War -19361939-), resulted in a deleterious delay in the progression of Fernando de Castro towards his main scientific objective, and before Christmas 1938, he knew that the Nobel Prize that year was awarded to Corneille Heymans... "for the discovery of the 
role played by the sinus and aortic mechanisms in the regulation of respiration" ${ }^{4}$ (Fig.

$2 \mathrm{H}-\mathrm{I})$. How important was Fernando de Castro for this research has been carefully depicted elsewhere, as well as it has been analyzed if the Prize should be shared by both researchers (Gallego, 1981; de Castro, 2009b; González et al., 2014).

After the end of the Spanish Civil War, Fernando de Castro was punished by the filo-fascist new political authorities, and although he was replaced in his university chair by 1950 , his scientific career was so abruptly interrupted that it was almost impossible for him to reach again the very first line in the field. Nevertheless, Fernando de Castro continued working in the sympathetic system and the $C B$ until his retirement (July 1966) and almost immediate death (April 1967), mainly interested in different aspects of synapses ${ }^{5}$ and always persecuting his dream to give histological descriptions a physiological explanation. It is out of doubt that, among the members of the Spanish Neurological School, Fernando de Castro was the most important contributor to our current knowledge about the PNS, and maybe one of the most relevant and diverse ${ }^{6}$ in his contributions in this field along the History of Science up to date.

\section{Acknowledgements}

$\mathrm{FdC}$ research group is currently financed by the Spanish Ministry of Science (former Ministry of Economy; grants SAF2016-77575-R and RD16/0015/0019 partially cofinanced by FEDER “Una manera de hacer Europa") and Fundación Inocente Inocente (Spain).

\section{FIGURE LEGENDS}

Figure 1: Fernando de Castro and the sensitive and sympathetic ganglia. A: Fernando de Castro circa 1922, when he got his Ph.D., working at the laboratory of the Medical School (Madrid). B: Image 23 of original Ph.D. thesis by Fernando de Castro (specific approval on the bottom-right: "O.P. Castro"), illustrating the plexiform ganglia of the

\footnotetext{
${ }^{4}$ Nobel Prize Database (https://www.nobelprize.org/prizes/medicine/1938/heymans/facts/)

${ }^{5}$ The very begining of this specific research line was: de Castro (1937).

${ }^{6}$ His works on the innervations of the pancreas (de Castro, 1923c) have not been revised in detail in this current work.
} 
vagus nerve from an alcoholic adult man; includes different degenerative forms. Typewritten legend corresponds to the Ph.D. thesis, too. C: de Castro's original drawing (see signature "De Castro" on the bottom-left) of a sympathetic lumbar ganglion in normal condition (human, 38-year old); the sections were stained with Cajal's method. It can be identified preganglionic $(\boldsymbol{a})$ and intraganglionic endings $(\boldsymbol{d})$ over dendritic bushes, accessory dendrites forming bushes $(\boldsymbol{b}, \boldsymbol{g})$, collaterals formed by other protoplasmic processes $(\boldsymbol{c})$ and a pericellular dendritic nest $(\boldsymbol{f})$. This schema was published in: de Castro, 1923a; de Castro, 1933. D: Another original drawing from de Castro illustrating large neurons from the lumbar ganglia in normal conditions (from an adult woman, 30-years old), stained with Cajal's method. A long dendrite (a) from the big neuron in the center, as well as other dendrites $(\boldsymbol{d}-\boldsymbol{g})$ receive connections from other preganglionic fibers. This drawing was first published in: de Castro, 1923a. E: Electromyographic recordings of the nictitating membrane of the adult cat where the sympathetic superior cervical ganglion has been cross-innervated with rami from the $\mathrm{VI}-\mathrm{C}$ and VII-c nerves. The intensity of the contraction correlates with the frequency of the tetanic stimulation. $\mathbf{F}$ : Schema of the preganglionic convergence of fibers $(\boldsymbol{a}-\boldsymbol{c})$ over ganglionic cells $(\boldsymbol{A}-\boldsymbol{C})$. The thickness of the fibers is representative of their thickness in vivo. Ganglion cells can trigger when activated simultaneously by two synaptic afferences, or in the slow fibers $(\boldsymbol{c})$ when a synchronic impulse via $\boldsymbol{a}$ - $\boldsymbol{b}$ facilitates it. E-F were first published in: de Castro and Herreros, 1945.

Figure 2: Hering, de Castro and Heymans and the anatomophysiological basis of the cardiorespiratory reflexes. A: Heinrich E. Hering. B: Classic experiment by Hering generating tachycardia and arterial hypotension after hanging 64 grams weight from the carotid sinus. C: Electrical stimulation (between arrows, on the bottom) of the sinus nerve gives rise to bradycardia and arterial hypertension. (B-C: Adapted from: Hering, 1927). D: Fernando de Castro ca. 1930. E: de Castro's original hand-drawing of the arterial chemoreceptors from the glomus caroticum (CB) of an adult cat (B/W published in: de Castro, 1926). F: de Castro's original schema showing the distribution of baroreceptors (in the carotid sinus) and chemoreceptors (confined to the CB; B/W published in: de Castro, 1940 -although the first scheme in this sense was included in: de Castro, 1928-). E-F: Graphite de Castro's handwritten instructions for publishers are conserved. G: Corneille Heymans. H: Recording in a healthy dog showing the effects of hypoxemia (activation of the chemoreceptors in the CB). I: Schema showing the relationship between the baroreflex and chemoreflex to regulate cardio-respiratory physiology. (H-I: Included by Heymans in his Nobel lecture, 1945). 


\section{Bibliography}

Andrés-Barquin PJ (2002) Santiago Ramón y Cajal and the Spanish school of neurology. Lancet Neurol 1:445-452. doi: 10.1016/S1474-4422(02)00192-8

Araque A, Parpura V, Sanzgiri RP, Haydon PG (1999) Tripartite synapses: Glia, the unacknowledged partner. Trends Neurosci. 22:208-215

Billingsley PR, Ranson SW (1918) Branches of the ganglion cervicale superius. J Comp Neurol 29:367-384. doi: 10.1002/cne.900290405.

Dale HH (1914) The action of certain esters and ethers of choline, and their relation to muscarine. J Pharmacol Exp Ther 6: 147-190.

Dale HH (1935) Dixon Memorial Lecture. Proc Roy Soc Med 28: 15-28.

de Carlos JA, Pedraza M (2014) Santiago Ramón y Cajal: The Cajal institute and the Spanish histological school. Anat Rec 297:1785-1802. doi: 10.1002/ar.23019

de Castro F (1916a) Nota sobre ciertas terminaciones nerviosas en el ganglio cervical superior simpático humano. Bol. Soc. Esp. Biol. 6, 63-68 6:63-68

de Castro F (1916b) Nota sobre la disposición del aparato reticular de Golgi en los botones gustativos. Trab Lab Invest Biol Univ Madrid 14:107

de Castro F (1920a) Algunas observaciones sobre la histogénesis de la neuroglia en el bulbo olfactivo. Trab. lab Invest. Biol. Univ. Madrid 18: 83-109

de Castro F (1920b) Estudios sobre la neuroglia de la corteza cerebral del hombre y de los animales. I. La arquitectura neuróglica y vascular del bulbo olfativo. Trab. lab Invest. Biol. Univ. Madrid 18: 1-35.

de Castro F (1920c) Nota sobre ciertas terminaciones aberrantes de fibras trepadoras estudiadas en el cerebelo del perro joven. Trab. lab Invest. Biol. Univ. Madrid 18: 199-206.

de Castro F (1922) Estudio sobre los ganglios sensitivos del hombre en estado normal y patológico. Formas celulares típicas y atípicas. Arch. Neurobiol. 3: 256-318.

de Castro F (1923a) Evolución de los ganglios vertebrales y prevertebrales. Conexiones y citotectonia de algunos grupos de ganglios en el niño y hombre adulto. Trab Lab Invest Biol Univ Madrid 20:113-208

de Castro $F(1923 b)$ Sobre la fina anatomía de los ganglios simpáticos de algunos mamíferos. Bol Soc Esp Biol Univ Madrid 10:92-97

Castro F. (1923c) Contribution a la conaissance de l'innervation du pancreas. Y-a-til des conducteurs spécifiques pour les îlots de Langerhans, pour les acini glandulaires et pour les vaisseaux? Trav. Lab. Rech. Biol. 21, 423-457.

de Castro $F$ (1925) Technique pour la coloration du système nerveux quand il est pourvu de ses étuis osseux. Trav Lab Rech Biol 23:427-446

de Castro F (1926) Sur la structure et l'innervation de la glande inter-carotidienne (glomus caroticum) de l'homme et des mammifères, et sur un nouveau système d'innervation autonome du nerf glosopharyngien. Trav Lab Rech Biol 24:365-432

de Castro F (1928) Sur la structure et l'innervation du sinus carotidien de l'homme et des mammifères:nouveaux faits sur l'innervation et la fonction du glomus caroticum. Trab Lab Invest Biol Univ Madrid 25:330-380.

de Castro $F$ (1930) Recherches sur la dégénération et la régénération du système nerveux sympathique. Quelques observations sur la constitution des synapses dans les ganglions. Trav Lab Rech Biol 26:357-456.

de Castro F (1932a) Sensory ganglions of the cranial and spinal nerves normal and pathological. In: Citology and Cellular Pathology of the Nervous System, Penfield,. 
Hoeber Publishers. I, New York. USA, pp 93-143

de Castro F (1932b) Sympathetic ganglia, normal and pathological. In: Cytology and Cellular Pathology of the Nervous System. ed. W.D. Penfield, Penfield,W. Hoeber Publishers. I, New York. USA, pp 317-319.

de Castro F (1933) Quelques recherches sur la transplantation de ganglionsnerveux (cérebro-spinaux et sympathiques) chez les mammifères. Etudes comparatives sur la capacité réactionnelle et la résistance vitale des neurones survivants dans les greffes. Trav Lab Rech Biol 27:237-302.

de Castro $F$ (1937) Sur la régénération fonctionnelle dans le sympathique (anastomoses croisées avec des nefs de type iso et hétéromorphe). Une référence spéciale sur la constitution des synapses. Trav Lab Rech Biol 31:271-345

de Castro F (1940) Nuevas observaciones sobre la inervación de la región carotídea. Los quimio y presoreceptores. Trab. Lab. Invest. Biol. Univ. Madrid 32, 297-384. de Castro F (1942) Modelación de un arco reflejo en el simpático, uniéndolo la raíz aferente central del vago. Nuevas ideas sobre la sinapsis. (Sensibilidad química y mecánica de los receptores del vago.). Trab Inst Cajal Invest Biol 34:217-301.

de Castro F (1944) Sobre el mecanismo de excitación de los quimioceptores y baroceptores del glosofaríngeo, utilizando un arco reflejo formado entre los sistemas vago-aferente y simpático. Trab Inst Cajal Invest Biol 36: 345-395.

de Castro F, Herreros ML (1945) Actividad funcional del ganglio cervical superior en relación al número y modalidad de sus fibras pregangliónicas. Modelo de la sinapsis. Trab. Inst. Cajal Invest. Biol. 37: 287-342.

de Castro F (1950) Die normale histologie des peripheren vegetativen nervensystems. Das synapsen-problem: Anatomisch-experimentelle untersuchungen. Verh Dtsch Ges Pathol 34:1-52

de Castro F (1951a) Aspects Anatomiques de la Transmission Synaptique Ganglionnaire chez les Mammifères. Arch. Int. Physiol. 59: 479-513 doi: 10.3109/13813455109150845)

de Castro F (1951b) Sur l'estructure de la synapse dans les chemoreceptors. Leur mechanisme d'excitation et rôle dans le circulation sanguine local. Acta Physiol. Scand. 22: 14-43.

de Castro F (1962) Sur la vascularisation et l'innervation des corpuscles carotidiens aberrants. Arch Int Pharmacodyn 139 : 214-224.

de Castro F, Rubio M (1968) Anatomy and innervation of the blood vessels of the carotid body and the role of chemoreceptive reactions on the autoregulation of the blood flow. In: Arterial Chemoreceptors. Proceedings of the Wates Symposium (ed. RW Torrance). Ed. Blackwell, Oxford and Edinburgh (United Kingdom).

de Castro F (1981) Cajal y la Escuela Neurológica Española. Ed. Univ. Complutense. Madrid, Spain.

de Castro F, Geijo-Barrientos E, Gallego R (1997) Calcium-activated chloride current in normal mouse sympathetic ganglion cells. J. Physiol. 498: 397-408.

de Castro F (2009a) The discovery of sensory nature of the carotid bodies. In: Advances in Experimental Medicine and Biology. pp 1-18

de Castro F (2009b) Towards the sensory nature of the carotid body: Hering, de castro and Heymans. Front Neuroanat 3:23. doi: 10.3389/neuro.05.023.2009.

de Castro, F. (2016) The Cajal School in the peripheral nervous system: the transcendent contributions of Fernando de Castro on the microscopic structure of 
sensory and autonomic motor ganglia. Front. Neuroanat. 10:43 (1-11).

de Castro F (In Press) Quizá la más exitosa escuela de la Historia de la Biomedicina:

Cajal y la Escuela Española de Neurohistología. In: Reconocimiento a cinco siglos

de Medicina española (eds: Álvarez Fernández-Represa, J., Gutiérrez-Fuentes, J.A.)

Ed. Fundación Ramón Areces and Real Academia de Doctores de España. Madrid, Spain.

del Río-Hortega P, Prado M (1942) Investigaciones sobre la neuroglia de los ganglios simpáticos. Arch. Histol. Norm. Patol. 1: 83-138.

Dogiel AS (Ed) (1908) Der Bauder Spinal ganglien des Menschen und der Säugetiere. Jena, Germany

Drüner L (1925) Ueber die anatomischen Unterlagen der Sinusrefl exe Herings. Dtsch. Med. Wochenschr. 51: 559.

Ehrlich P (1888) Ueber einen Fall von Anämie mit Bemerkungen über regenerative Veränderungen des Knochenmarks. Charité-Annalen 300-309.

Gallego A (1981) Fernando de Castro (1896-1967). In: "Cajal y la Escuela Neurológica Española" (de Castro F). Ed. Univ. Complutense. Madrid, Spain.

Gómez-Santos M (Ed) (1968) Cinco grandes de la Ciencia española. Ed. Taurus. Madrid, Spain

Gómez-Santos M (Ed) (2009) Fernando de Castro. Su vida, su obra. Ed. Fundación Médica Mutua Madrileña. Madrid, Spain.

González C, Conde SV, Gallego-Martín T Olea E, González-Obeso E, Ramírez M, Yubero S, Agapito MT, Gómez-Niño A, Obeso A, Rigual R, and Rocher A. (2014) Fernando de Castro and the discovery of the arterial chemoreceptors. Front. Neuroanat. 8, 25 (1-16).

Hëring H (1923) Der Karotisdruckversuch. Münch Med Wochenschr 42: 1287-1290

Hëring H (1924) Der Sinus caroticus an der Ursprungsstelle der Carotis interna als Ausgangsort eines hemmenden Herzreflexes und depressorischen Gefässreflexes. Münch Med Wochenschr 71: 701-XXX.

Hëring HE (ed) (1927) Die Karotissinusreflexe auf Herz und Gefässe,vom NormalPhysiologischen. Ed. Verlag von Theodor Steinkopff. Dresden and Leipzig, Germany.

Heymans J, Heymans C (1927) Sur les modifi cations directes et sur la régulation réfl exe de l'activité du centre respiratoire de la tête isolée du chien. Arch Int Pharmacodyn 33:273-370.

Jacobovici J, Mitzescu II, Pop A (1928) Sur la fonction de la glande (paraganglion) carotidienne. La glande et le réflexe du sinus carotidien. Compt Rend Soc Biol 98:640-643

Kolossow NS, Sabussow SH (1932) Zur Frage der Innervation des menschlichen MagenDarmkanals. Z Mikr Anat Forsch 29:541-560.

Langley JN (1903) The autonomic nervous system. Brain 26:1-26. doi: 10.1093/brain/26.1.1

Lawrentjew BJ (1934) Einige Bemerkungen über Fortschritte und Aufgaben der Erforschung des autonomen Nervensystems. Ztschr. F. Mikr. Anat. Forsch. 36: 651-659.

Loewi O (1921) Über humorale Übertragbarkeit der Herznervenwirkung. I.Mittei-lung. Pflügers Arch Ges Physiol 189: 239-242.

Marani EE, Lakke EAJF (2012) Peripheral Nervous System Topics. In: The Human 
Nervous System. pp 82-140

Marinesco G, Minea J (1912) Essai de culture des ganglions spinaux de mammifères in vitro: contribution à l'étude de la neurogénèse. Anat Anzeiger 42:161-176

Marinesco G, Minea J (1914) Nouvelles recherches sur le cultive in vitro des ganglions spinaux de mammifères. Anat Anzeiger 46:529-547

Merchán M, DeFelipe J, de Castro F (Eds) (2016) Cajal and de Castro's Neurohistological Methods. Oxford Univ. Press. Oxford, United Kingdom.

Perea G, Navarrete M, Araque A (2009) Tripartite synapses: astrocytes process and control synaptic information. Trends Neurosci. 32: 421-431.

Purves D, Lichtman JW (1985) Geometrical differences among homologous neurons in mammals. Science 228: 298-302.

Ramón y Cajal S (Ed) (1923) Recuerdos de mi vida. (3rd edition). Ed. Imprenta de Juan Pueyo, Madrid (Spain).

Ramón y Cajal S (1933) Neuronism or Reticularism [Neuronismo o reticularismo]. Arch. Neurobiol. 13: 218-579.

Ramón y Cajal S, de Castro F (Eds) (1933) Elementos de Técnica Micrográfica del Sistema Nervioso. Ed. Tipografía Artística. Madrid, Spain

Terni T (1914) Sulla correlazione fra ampiezza del territorio di innervazione e volume delle cellule gangliari. I. Richerche sui gangli spinali della coda di Cheloni. Anat. Anz. 49: 369-386.

Tremblay M-È, Lecours C, Samson L, et al (2015) From the Cajal alumni Achúcarro and Río-Hortega to the rediscovery of never-resting microglia. Front. Neuroanat. 9: 45. doi: 10.3389/fnana.2015.00045 